\title{
Islamic Education and Multiculturalism: Engaging with the Canadian Experience
}

\author{
Faisal Ali \\ Iqra Islamic School, Surrey, BC \\ Faisalali21@gmail.com \\ Carl Bagley \\ University of Durham, UK \\ c.a.bagley@durham.ac.uk
}

\begin{abstract}
Canada has a long history of immigration by diverse ethnic minority groups arriving in the hope of establishing economically successful - yet socially and culturally distinct communities based on particular values and beliefs not necessarily shared by the ethnic majority. In recent years however the arrival of new immigrants whose values differ from the mainstream has intensified the multicultural debate, as the aspirations and needs of ideologically-motivated minorities feel current policies and institutions marginalize their values and beliefs (not dissimilar to that historically encountered by Canada's indigenous people). As a result of these social divergences, the secular state and orthodox religious groups often compete for the hearts and minds of children. Consequently as Muslim communities in Canada seek to protect their children and youth from perceived negative outside influences so Islamic schools have been established. Such schools face particular challenges in negotiating the tensions between their aspiration to preserve Islamic values and wider socio-political pressures to integrate into Canada's multicultural society as a whole. This article engages with this tension to uncover and explore the nature of Islamic education and its potentially contested relationship with Canada's multicultural ideals. In concluding it reflects on possible ways in which multicultural-Islamic education tensions might be ameliorated.
\end{abstract}

\section{Introduction}

Western democracies such as Canada have an ongoing history of ethnic minority immigration with diverse groups arriving in the hope of establishing economically successful - yet socially and culturally distinct - communities based on particular values and beliefs not necessarily shared by the ethnic majority. Consequently, as these democracies come to terms with increasing levels of social pluralism, so the discussion around minority rights comes to the fore. Liberal states face the problem of defining citizenship in light of what Kymlicka (1994) calls "constituent communities", that is, two or more groups who share a national border but hold radically different cultural views. The tension is particularly acute between the liberal state and those communities "which do not favour or promote individual autonomy, but prefer to see the individual as closely bound within the traditions of the group" (Burtonwood 2000, pp 269-270). Minority religious communities frequently experience hard choices as first and second generation immigrants seek to negotiate between the cultural values and traditions of their families and religion and the cosmopolitanism of their secular host nation. As Zine (2007) observes, many newcomers from the Muslim world face particular temptations and challenges such as whether or not to engage in mainstream social customs which may include consuming alcohol, dating, and premarital relations. 
As a result of these social divergences, the secular state and orthodox religious groups often compete for the hearts and minds of children. In this context the academic environment which dictates what is taught, how it is taught, and by whom, takes on a specific significance. For example, Muslim students in public school systems face cultural challenges including issues related to gender sensitivity, such as modest dress (e.g., the hijab), sanctioned food (halal), provisions for prayer, and character education (Merry 2005). In addition, as Elmasry (2005, p. 6-7) observes, "Prejudice against Canadian Muslims today is compounded by media stereotyping that has built an image colouring them all terrorists, potential terrorists or terrorist sympathizers. They are marginalized as having values different from Canadian values."

Against this socio-political backdrop, Muslim communities in Canada seek to protect their children from the negative outside influences of the dominant culture, while at the same time striving to integrate positively with the wider society (Zine, 2007). Islamic schools in Canada provide a safe learning environment in which students preserve their beliefs, identity, and cultural heritage, are protected from cultural assimilation, racism, and discrimination (Hewitt, 1997; Zine, 2007). In seeking to fulfil this role Islamic schools are constantly accused of isolating their students from the wider society, and as a result are accused, at best, of hindering their students' positive integration with the society at large, and at worst, of indoctrinating them with fundamentalist, divisive, and intolerant ideas towards non-Muslims (Hewitt, 1997; Merry, 2007; Zine, 2007). Thus while it is not the intent to downplay the cultural isolationism, discrimination and prejudice encountered by other ethnic minority in Canada's nor indeed by its indigenous people, Islamic schools in Canada face particular challenges in negotiating the tensions between their aspiration to preserve Islamic values and wider socio-political pressures to integrate into Canada's multicultural society as a whole (Grant, 1997). This article engages with this tension to uncover and explore the nature of Islamic education and its potentially contested relationship with Canada's multicultural ideals.

\section{Islamic Education}

Islamic education delivered through private Islamic schools, is currently widespread in Europe, the US, and Canada (Ramadan, 2004). An Islamic education presents Islam as a way of life that aims at establishing an ideological community (ummah) with universal principles based on the teaching of the Qur'an and the traditions of Prophet Muhammad (Halstead, 2004). These schools establish not only the spiritual and ethical guidelines of Islam, but also make it the primary source of identity for Muslims. An Islamic education focuses mainly on individual and social development. In individual development, the education strives to provide students with the skills and knowledge necessary to succeed in life and to achieve positive rewards in the hereafter. Socially, Islamic education focuses on enhancing the community's collective identity and preserving its cultural heritage (Halstead, 2004). According to Islam, the concept of community consists of the family and the wider global community of believers (ummah) under the umbrella of Islamic law (shari'ah). The Islamic world view is that Islam is a way of life with universal values which are based on the Qur'an and the teachings of Prophet Muhammad that focus on creating a united ideological community. The Qur'an and the traditions of Prophet Muhammad (PBUP) provide balanced guidelines that cover spirituality and ethics as well as other parts of life. Islamic law is also a major source of identity for Muslims. Therefore, while Islam recognizes other identities, it definitely favours the Islamic identity above other identities. Islam, in this context, provides harmony and unity, which enables its members to develop common centres and institutions such as mosques and schools (Halstead, 2004). In Islam, social existence and individual 
existence have the same goal, which is "the realization on earth of divinely ordained moral imperatives. Indeed, the growth of an individual can only take place within the shari'ah" (Halstead, 2004, p. 523). The Islamic shari'ah (divine law) provides a guideline of God's commands for Muslims in their private life as well as in their social life (Halstead, 2004).

In the Islamic world view each person consists of a soul and a body that, according to Islamic philosophy, needs knowledge. Such knowledge should combine the secular (rational or intellectual sciences) and religious (revealed knowledge). Both should lead to the worship of the creator (God-Allah) (Tan, 2011). The concept of separation between religious education and secular education does not feature in Islamic education (Abdullah, 1982; Douglas \& Shaikh, 2005). Islamic teaching promotes integration of both religious and secular educations, which aims at producing a well-rounded person who is not only faithful to God, but also equipped for success in everyday life (Abdullah, 1982; Delic, 2006).

Underlying Islamic theology is the notion that humans are created in a state of fitrah (by decree) with the ability to worship (ibaadah), and obedience (ta' $a h$ ) to the commands of Allah (God) (Merry, 2007). Worshiping and obeying Allah means devoting all human activities in life (including education) to achieving tawhid (Oneness of God), that is, to worship Allah alone to gain his blessings. Thus the primary goal of Islamic education is to promote a complete submission to the will of Allah (Merry, 2007), and the curriculum in Islamic schools must be taught from an Islamic standpoint. Proponents of Islamic education argue that the curriculum provides a balanced and integrated faith-based education system that strives to educate the whole person and empowers students' cultural/religious identity (Abdullah, 1982; Ashraf \& Hussain, 1979; Cook, 1999; Merry, 2007; Thomas, 2002). It is important to note that there are many teachings in Islam that promote anti-racism, fairness, justice and respect to all people's dignity irrespective of their diverse backgrounds (AbdulAziz, 1992; Emerick; 1998, 2000, Philips; 1997). In this context, to ensure that difference is treated as acceptable rather than a sign of deficiency, an Islamic education curriculum aims to develop in students' positive attitudes, skills and knowledge to strengthen their Islamic identity and teach them to live with others in peace and harmony (Abdul-Aziz, 1992, Emerick, 1998, 2000; Philips, 1997).

The following key terms, ta'lim, tarbiyah, and ta'dib, are used in Arabic to describe education (Cook, 1999). Each term enhances a specific dimension of an Islamic education. These terms are further interrelated in their concern for individuals, the community, and society as a whole, and represent the scope of education in Islam. The first term, ta'lim, means to know, to learn, or to be aware. It is directly related to instruction that involves mental activities and results in knowledge that the student did not previously possess. It can be defined as the process of transmitting or imparting knowledge to a person that will help in training his or her mind, while developing reasoning power. Thus, ta'lim implies the process of instilling knowledge in somebody so that this knowledge provides meaning and value to human life and to all human activities (Bin Omar, 1993). The second term, tarbiyah, comes from the root raba, and means to increase, to grow or to nourish, to perform the gradual process of bringing or growing of something to the stage of completeness or maturity (Cook, 1999, pp. 344-345). In contemporary Arabic usage, tarbiyah is a matter of putting affairs right, and in a proper state, or order (Ibn Manzur, 2000, Vol. 1). The term further describes a state of spiritual and ethical nurturing that is in accordance with the will of the Ar-Rab (the Lord). Consequently, the task of Islamic education is"the vivid presentation of high values and continued exposure to the attraction of goodness, truth and honesty until they are woven into the fabric of personality" (Hajalton, 1982, p. 59). Moreover, Thomas (2002, p. 3) points out, in the world view of tawheed (divine unity), knowledge is one entity, and cannot be divided into secular and religious divisions. Therefore, Islamic education focuses both on training the mind and the passing of knowledge (ta'lim) to others, as well as educating the 
person as a whole (Thomas, 2002, P. 3). The teacher is not only a teacher (mu'alem) but also a murrabi, or a trainer of souls and personalities. Both kinds of knowledge contribute to the strengthening of faith (iman) (Thomas, 2002, p. 3). The third term is ta'dib. This word comes from the root of ad-daba, which means to be cultured, well mannered, refined, or disciplined. It describes good social behaviour. According to Ibn Omar (1993, 5-10),"It is a process by which are acquired the good qualities and attributes of the mind and soul in terms of proper behaviour or ethical conduct." The function of Islamic education is to produce men and women who possess characteristics and manners resembling Prophet Muhammad - the ideal role model in all aspects of life_-as closely as possible (Cook, 1999; Shaikh, 1996). As Delic (2006, p. 36) says:

In Islam, education can never be separated from adab in its most educational sense, because adab encompasses the spiritual level of human awareness. Because of this inner nature of Islamic education, it is impossible, theoretically speaking, to find an educated person, in the Islamic sense, who is an immoral person. The emphasis on adab, which includes action (a'mal) in education and the educational process, ensures that 'ilm (knowledge) is being put to good use in society.

In Islam, the Qur'an, and the traditions of Prophet Muhammad are the core framework of belief and action on which Islamic thought and philosophy of education are built (Abdullah, 1982; Cook, 1999; Hewitt, 1997; Tan, 2011). For Muslims, Islam represents their ideological world view, comprising a set of beliefs, practices and values. It includes both religious beliefs and cultural practices necessary for the formation of a cultural identity (Maududi, 1998; Tan, 2011). Islamic education depends on a teaching methodology where independence of thinking is not encouraged (Cook, 1999; Ramadan, 2004). Rather, students are expected to receive information from their teachers and there is very little opportunity to question, contribute, and challenge such information. In theory Islam advocates that students develop the necessary skills and knowledge for personal growth, autonomy, and freedom. It also encourages young Muslims to express themselves, to become critical thinkers, question ideas and concepts, and engage in debate in a supportive environment. However, in practice, students in Islamic education classes in the West are often encouraged to be good listeners, and respectful of what they are told, without any critical thinking (Ramadan, 2004)

Because the key aspiration of Muslim communities in the West is largely to preserve the values and identity of Islam for their children (Ramadan, 2004), this mission is emphasized in Islamic schools. Consequently, there is an inherent imbalance between maintaining Islamic fundamentals and providing students with the necessary knowledge and skills to reconcile any tensions that may exist between their religious and national identity. Thus while Canadian public schools encourage students to think critically, express their views, question ideas, and engage in debate, educational programmes in Islamic schools still have a long way to go in facilitating similar competencies (Cook, 1999). Cook (1999) and Ramadan (2004) argue that a close examination of the Islamic education curriculum in the West indicates that it focuses on protecting students from the perceived negative influence of the West by isolating them from non-Muslims and non-Islamic traditions. As a result, many students memorize long chapters of the Qur'an as well as many traditions of the Prophet (ahadith) that have no impact on their daily life in the country where they live (Ramadan, 2004). Focusing on Qur'an memorization and recitation without understanding the text has a great influence on how students approach learning (Cook, 1999). It has been claimed that many students who graduate from Islamic schools possess an admirable ability to memorize, but lack competence in critical analysis and independent thinking (Cook, 1999). Certainly advocates of a secular public system consider religious education to be a rejection of liberal 
democratic values, deliberately intended to isolate students from the wider society, promoting a separatist cultural heritage that also limits students' opportunity to engage in an open dialogue and critical thinking (Banks, 2001; Gutmann, 1996; McKinney, 2006; Sweet, 1997). Moreover, the content of the Islamic curriculum seems to be directed at students who reside in predominantly Islamic countries rather than the multicultural Western environment in which they live. As Merry (2007) notes, the philosophy of Islamic education is based on theology, as all aspects and actions in Islam have God (Allah) as their focal point. The philosophy of Islamic education is developed for the Muslim ummah (community of believers) especially in the Muslim world. In practice, that presents a challenge for Muslim schools in the West. As Merry remarks:

The incongruence between an ideal type of philosophy of Islamic education and the heterogeneous body of Islamic schools in the West is admittedly an antinomy of sorts. In part, this tension exists because virtually all Islamic philosophy of education is derived from so called Muslim world (Merry, 2007, p. 46).

Muslim students are being taught that they are different from the 'other', the Westerner, whose cultural traits and behaviour they shouldn't adopt (Cook, 1999). Such teaching has particular consequences, according to Ramadan (2004), who claims that it can instil:

....an uneasiness and an inferiority complex almost impossible to live with: eventually, the religious and spiritual education that is provided and that should give the young and the not young the means to confront the challenges of their society pushes them along one of three avenues: to pretend, to lose themselves in silence, or to reject everything and rebel... (Ramadan, 2004, p. 128).

This viewpoint contrasts with the opinions of proponents of religious education (including Islamic schools) who believe that such schools promote particular cultures and religions that aim at moving the experiences of their students to the core of educational discussion, rather than remaining marginalized (Ameli et al., 2005). In addition, it is argued that faith-based schools improve, rather than hinder social harmony in a multi-cultural society, because they allow cultural and religious communities to maintain their specific religions and cultures, (Ameli et al., 2005; Thessen, 2001). Halstead (2004) maintains that the aspiration of Islamic education to preserve a community's cultural heritage is a challenge, as it may conflict with the nature and spirit of the multicultural policies in the West that are meant to accommodate different people from many cultural and religious backgrounds.

\section{Multiculturalism}

Ghosh (2004) points out that, ideally, multiculturalism and multicultural education policy promote equality, respect for human rights, and harmony and tolerance among diverse groups regardless of their languages, religions, cultures, or ethnicity in a pluralistic society. An individual can freely identify himself with two or more cultural identities. For example, one can be both Ukrainian and Canadian at the same time. For Hall (2000, p. 209) the term multicultural "describes the social characteristics and problems of governance posed by any society in which different cultural communities live together and attempt to build a common life while retaining some of their original identity." He further states that the term describes "the strategies and policies adopted to govern and manage the problems of diversity and multiplicity which multicultural societies throw up." In this context, the state should manage 
multiculturalism in a manner that fully accommodates diverse communities and groups in different societies (Nye, 2007:110). Multiculturalism does not describe a particular ideology, but rather a process that occurs in different settings and times; a process requiring both respect for difference as well as a sense of common ground (Nye, 2007: 110). It is a method for managing diversity in society.

In line with the broader concept of multiculturalism, multicultural education attempts to equip ethnic and cultural groups with an understanding of, and respect for, the unique cultures of other ethnic groups (Banks, 1994). As Gay (1985) observes,

Multicultural education is the policies, programs, and practices employed in schools to celebrate cultural diversity. It builds on the assumption that teaching and learning are invariably cultural processes. Since schools are composed of students and teachers from a wide variety of cultural backgrounds, the best way for the educational process to be most effective for the greater number of students is for it to be multicultural (Gay, 1985, p. 3).

Multicultural education further aims to eliminate cultural stereotypes and reduce the discrimination that some minority groups face in schools and in the wider society (Banks, 1994). Banks argues that many practitioners have a limited concept of multicultural education, and view it primarily as curriculum reform. For Banks and more recently Grant \& Sleeter (2006), multicultural educational changes need to include institutional changes in the teaching materials, teaching and learning styles, the attitudes, perceptions, and behaviours of teachers and administrators, and the goals, norms, and culture of the school. Most importantly multicultural education must be perceived as relevant for all students not simply those of colour or from minority ethnic backgrounds (Grant \& Sleeter, 2006).

Canada's federal government has made a firm commitment to multiculturalism. The objectives of Canada's multicultural system are, briefly, to promote understanding, equality, co-existence, harmony, and respect among all Canadians, regardless of their religious or ethnic background, to eliminate any discriminatory barriers and to help different groups to preserve their cultures and identity (Esses \& Gardner, 1996). The role of education is to provide students with the knowledge and skills to realise these multicultural ideals (Ghosh, 2004). In his 1971 speech on multiculturalism, then-Prime Minister Pierre Trudeau outlined the steps that the federal government would take to support and promote this policy (see Adams, 2007, p. 11-12):

1. Resources permitting, the government will seek to assist all Canadian cultural groups that have demonstrated a desire and effort to continue to develop a capacity to grow and contribute to Canada.

2. The government will assist members of all cultural groups to overcome cultural barriers to full participation in Canadian society.

3. The government will promote creative encounters and interchange among all Canadian cultural groups in the interest of national unity.

4. The government will continue to assist immigrants to acquire at least one of Canada's official languages in order to become full participants in Canadian society.

The Canadian Charter of Rights and Freedoms, guaranteeing equal protection and benefit of the law, and freedom from discrimination on the basis of gender, religion, and racial or ethnic background was approved in 1982. The Charter was followed in 1988 by the Multicultural Act, which further strengthened multiculturalism as a fundamental characteristic of Canadian society. This Act provided a legal avenue to guide the federal government's responsibilities and activities related to multiculturalism. In addition to 
guaranteeing equal opportunity for all Canadians regardless of origin, it focused on the rights of people of different ethnicities, races, and religions to preserve their unique cultural heritage. It also underlined the importance of eliminating any kind of systematic discrimination, and required all federal government institutions to implement their programs in a manner that reflects the new reality of the Canadian society. The Act also provided for funding to police departments, hospitals, and schools to implement multicultural policies (Hyman, Meinhardt \& Shields, 2011).

Federal policy objectives established in 2009 aim at creating a more cohesive, integrative society, with institutions that reflect Canada's diverse population (Hyman, Meinhardt \& Shields, 2011, pp. 6-7). Because Canada enjoys relatively harmonious relationships among her minority groups, and with society at large, Canada is widely viewed as among the most tolerant countries in the world (Adams, 2007, p. 13). For example, a survey conducted by the United Nations Human Development Index concluded that Canada is among the top 10 most tolerant countries in the world (Canada Immigration Newsletter, July, 2007). The survey focused on issues such as literacy and education, living standards, and life expectancy. Another survey conducted in 23 countries with more than 32,000 respondents concluded that Canada is the most tolerant country in the Western world, and ranked at the top in welcoming Muslims (Canada Immigration Newsletter, February, 2007). In comparison to Europe, according to Adams (2007), Canadians are more accepting of multiculturalism, and acknowledge the reality that their country is becoming more and more diverse.

Nonetheless as Masood (2007) notes, notwithstanding Canada's apparent success in achieving harmony and peace among the diverse communities the emergence of al Qaeda, the events of 9/11 and the apparent support of a small number of Muslims for al Qaeda's violent vision is redefining citizenship and access to justice in the Western world in general. In Canada, Maher Arar, a Syrian-born Canadian, was handed over to Syrian officials by the CIA with the full cooperation of Canadian security agencies. Mr. Arar, who was suspected of having links to al Qaeda, suffered severe torture while in a Syrian prison, before a public outcry led to the federal government's intervention, resulting in his release (Bakht, 2008). In light of the Arar case, the Canadian government subsequently established a commission to study post-9/11 injustice. The commission concluded that there was Canadian complicity in Arar's imprisonment and torture, and offered an official apology and financial compensation..

According to Kymlicka (2006), multiculturalism in Canada was originally established for the benefit of well-integrated European ethnic groups who had only minor differences in terms of culture and language with the dominant group. For example, Ukrainians, Italians, and other European immigrants led the multiculturalism discussions and debates in the 1960s and 1970s. Kymlicka argues that multiculturalism in Canada was not initially intended to accommodate Canadian Muslims, or to enhance their positive integration into the wider Canadian society It can be argued that when multiculturalism was introduced it was a reasonable response to already established communities of immigrants, but lacked flexibility in accommodating the needs of new immigrants, and did not consider, let alone address, the challenges faced by Muslims and similar minorities in their struggle to survive (Kymlicka, 2006).

In focusing on issues related to public institutions, and addressing the needs of secular ethnic minority groups, especially from Europe, Canada's multiculturalism arguably fails to accommodate the aspirations and needs of ideologically-motivated, diverse religious minorities. These religious minorities, including Muslims, feel that the current liberal multicultural and educational policies and institutions marginalize their values, beliefs, language and history, while simultaneously privileging the majority's (Azmi, 2001; Kymlicka 2006; Zine, 2007). For example when Ontario Muslims asked the provincial government to 
have their faith-based arbitrations system regulated by the courts, an opportunity enjoyed by other religious groups, the government responded by scrapping its recognition of all faithbased arbitrations (Biles, Ibrahim \& Tolley, 2010; Elmasry, 2005). Arguably, feelings of marginalization among Canadian Muslims have weakened their trust in the dominant majority and slowed their positive integration with Canadian society in general (Elmasry, 2005).

The seeming unwillingness of some sections of the Canadian Muslim community to accept liberal multiculturalism does not mean that Muslims oppose multiculturalism per se, for the Muslim community itself is very diverse and multicultural (Azmi, 2001). However, as Azmi (2001) suggests, some Muslims have significant problems with a liberal multiculturalism that directs them to marginalize religious values and beliefs in favour of secular inclusiveness. According to Biles, Ibrahim \& Tolley (2010) religion represents a particular challenge in Canada because it is often not dealt with directly. Thus while the Canadian Multiculturalism Act mandates the program address religion, in reality little attention is given to religion and religious communities in Canada, especially Islam. As Ibrahim \& Jahevich (2004, p. 49) observe, "while other religious minorities have been addressed under the categories of race or ethnicity, due to the heterogeneous Muslims population, ethnic, race or linguistic categories are not adequate to address the religious needs of Muslims."As a result, there are tensions between preserving Muslims' religious identity and the government's multicultural policy regarding minority concerns.

\section{Islamic Education and Multiculturalism: Possibilities and Prospects}

Modood (2005) argues that separating politics from religion hinders the development of a balanced multicultural system, because it negates the important role of religious groups in any society. Consequently, a multicultural state should not be a radically secular state; instead, it should give religious communities an equal opportunity to play a central role in the political life of their respective societies. Modood further argues that religious convictions should be treated with the same respect that is accorded other categories such as gender and race. In short, Muslims should be accepted as a genuine group with a common belief system (as distinct from their ethnic identities as, for example, Asians), whose presence has to be recognized and reflected in all parts of the society. Modood (2007 in Meer \& Modood, 2009) proposes considering multiculturalism as a civic idea that can be integrated into an inclusive national identity. He proposes promoting strong citizenship identity that fosters commonality and strengthens national identities, while preserving differences in various aspects:

...it does not make sense to encourage strong multicultural or minority identities and weak common or national identities; strong multicultural identities are a good thing - they are not intrinsically divisive, reactionary or subversive - but they need the complement of a framework of vibrant, dynamic, national narratives and the ceremonies and rituals which give expression to a national identity

(Modood, 2007c in Meer \& Modood, 2009, p. 489).

Modood's (2007) perspective in bringing religion to the multicultural discussion side by side with ethnicity and race, and considering multiculturalism as a civic idea that can be integrated into an inclusive national identity, may help Western societies become more reflective of the needs of different groups including religious groups. It may also contribute to influencing decisions that relate to employment and government services, equality, and preserving religious identity. The development of a common national citizenship may create a strong sense of national identity that respects differences in religion in line with ethnicity and race. Developing multicultural competence and positive change requires that all parties 
be willing to engage in a fruitful dialogue to create a peaceful, diverse society that coexists harmoniously with one another (Banks, 1994; Modood, 2007)

According to Nye (2007, p. 113), an effective dialogue in multicultural societies, includes systematic steps towards recognizing differences, gaining knowledge of differences, and promoting tolerance and engagement across those differences. Nye argues that while this dialogue is critical in successfully managing multiculturalism in any society, it is just the starting point and not the end itself. The second step requires us to observe differences, a two-way street in which all participants must observe and learn about each other. This poses the danger that we may not be happy with some elements of particular cultures (Nye, 2007). In addition, there is the need for multicultural engagement, which has both positive and negative implications. Beyond recognizing cultural differences, tolerance is required at both the state and individual levels. Accepting religious or social practices ideas, values and practices that may not be agreeable to the majority culture presents some challenges. This works both ways, according to Nye (2007). Minorities must also respect and tolerate majority practices. For example, from an Islamic perspective, it may be difficult to tolerate native British values (Nye, 2007). Successful multiculturalism and cultural engagement requires mutual tolerance.

However, according to Nye, tolerance has its limitations and is not the end product of cultural engagement. But who decides such limitations? That is the challenge for multiculturalism. Mutual respect among cultures must include tolerance for diversity, and agreeing to a mutual goal that unites the different groups within any multicultural setting. As Nye observes, a successful multicultural society will integrate all these concepts, and ensure that the process is consistently maintained. This requires engagement among groups and individuals across the range of cultures, religions, and values. Such an engagement must be based on knowledge of each other, as well as tolerance and mutual respect for differences, along with acknowledgement of some common ground to which all belong.

Arguably, the current curriculum and teaching methodology of Islamic education in the West have not provided students with the necessary skills and knowledge to face the challenges posed by their societies. Ramadan (2004) observes that, for example, the curriculum is limited to the very technical memorization of the Qur'an verses, prophetic traditions, and values, and ignores the North American and European realities. The content of the curriculum seems to be directed to students living in the Muslim world and emphasizes the differences of these students' society from the society of others, rather than assisting them to find a balance between their Islamic identity and loyalty to their respective nations. It would be a mistake to argue that an Islamic education program does not teach any multicultural competence skills, since the program promotes qualities such as respect for others that indirectly lead to multicultural competence. However, a high level of multicultural competence requires, in addition to respect for others, an understanding of, and willingness to take responsibility for the rights of others (Esses \& Gardner, 2006). Ramadan argues that the Islamic curriculum needs to be flexible and reflective of the reality of Western societies. Consequently, while Islamic education in the West enhances students' faith and identity, it needs to challenge them to balance their faith and identity within their respective multicultural societies. Such balance requires openness and courage in critically questioning and discussing different viewpoints

Ramadan (2004) proposes a model for curriculum development based around three key principles: Education of the heart, education of the mind, and education for personal growth. The focus on the education of the heart is to strengthen students' belief system and their consciousness with God, and to make them aware of their responsibilities toward themselves, their relatives, their communities and humanity. The aim in educating the mind is to enhance students' understanding of the message of the revealed sources, of the Qur'an and 
the teachings of Prophet Mohammed, to help them develop good understanding of the main message of these sources in order to lead a life in this world that is in accordance to the guidelines of these sources, worshiping God (Allah) alone with the expected outcome of success in this world and in the hereafter. The final objective-education for personal growth-is to help students develop the necessary skills and knowledge to become autonomous in their lives and their choices.

Ramadan (2004) believes that studies of the Qur'an, traditions of the Prophet (ahadith), law, and jurisprudence, should take into consideration the environment and the context in which such learning takes place. Students must be provided with the necessary skills and knowledge needed to independently propose solutions for their personal and collective concerns. To reach the goal of independent thinking, the Islamic curriculum in the West must provide a body of teaching that encourages a sense of Islamic identity through prayer and observances such as fasting through Ramadan, but also through interacting with teachers and other students, and the wider society (Ramadan, 2004).

Finally, the literature suggests that although, Islamic educational institutions benefit from the multicultural system in Canada, they also face unique challenges that stem from the tension between the sometimes-opposing Islamic and liberal educational systems. If there is a hope of creating better integrated students, the Islamic education curriculum should find a balance between preserving students' beliefs and Islamic identity, and enhancing their multicultural competence. To this end, the Islamic education program should expand the concept of respect to include non-Muslims' beliefs and cultures, and define good Islamic practices to include good citizenship in the multicultural context (Ramdan, 2004). In addition, such curriculum should be taught within the context of Canada's multicultural society by locally trained teachers who are well versed with modern teaching pedagogies. In return, Canada's public schools, government agencies, and media outlets should develop policies aimed at challenging Islamophobia and present Islam from a perspective of peace and social justice, and not from the negative images which present Islam as a religion based on extremism (Zine, 2004). 


\section{References}

Abdul-Aziz, M. (2001). Studies in Islam. New Delhi : Islamic Book Services..

Abdullah, A. (1982) Educational theory: A Qur'anic outlook. Makkah, SA: Umm Al-Qura University Press.

Adams, M. (2007) Unlikely utopia: The surprising triumph of Canadian pluralism. Toronto: Penguin Group.

Ameli, S.R; A. Azam, and A. Merali (2005). Secular or Islamic? What schools do British Muslims want for their children? Wembley, UK: Islamic Human Rights Commission.

Anees, M.A., and Athar, A.N. (1980). Educational thought in Islam. Hamdar Islamicus 3(2) 47-77.

Anzar, U. (2003) Islamic education: A brief description of history of madrasas with comments on curriculum and current pedagogical practices. Retrieved in July 17, 2007 from: http:// www.uvm.ed/ envprog/madrassah/madrassah.

Asharaf, S.A. and Hussain, S.S. (1979). Crisis in Muslim education. Makkah, SA: King Abdul Aziz University Press.

Azmi, S. (2001). Muslim educational institutions in the United States and Canada: Conception and practice of the Islamic belief system, in Y. Haddad (Ed.).The Muslims of America (157-174). Boston: Blackwell Publishers.

Bakht, N. (2008). Belonging and banishment. Toronto: TSAR Publications.

Banks, A. J. (1994). Cultural diversity and education: Educations, curriculum and teaching. Bostyon: Allyn and Bacon.

Biles, J., Ibrahim, H., and Tolley, E. D. Does Canada have a multicultural future?

Retrieved in 2010) from: $w w w$.

Canda.metropolis.net/pdfs/does_canada_have_multicultural_future_e.pdf.

Bin Omar, A. (1993). In quest of an Islamic ideal of education: A study of the role of the traditional Pandok Institution in Malaysia. Unpublished doctoral dissertation, Temple University, Philadelphia.

Burtonwood, N. (2000). Must liberal support for separate schools be subject to a condition of individual autonomy? British Journal of Educational Studies, 48, 269-284.

Canada Immigration Newsletter, (July, 2007). Canada's 140th birthday a multicultural celebration. Retrieved in July 20, 2009 from: http://www.cicnews.com/2008/12/canada-welcomingcountry-world-12691.html .

Cook, B. (1999). Western conceptions of education. International Review of Education. Kluwer Academic Publishers. Netherlands.

Delic, Z. (2006). Hermeneutics of Islamic education and the construction of new Muslim cultures in the west: Faithful but reformed. Unpublished Ed.D dissertation. Simon Fraser University, Burnaby BC.

Elmasry, M.; (2005). Towards Smart Integration: The Choice of Canadian Muslims. The Canadian Islamic Congress, Ontario. A paper presented at The 10th International Metropolis Conference, Toronto, October 19, 2005. Retrieved in July 2009 from: www.canadianislamiccongress.com

Emerick, Y. (1998). Learning About Islam. New York: International Books \& Tapes Supply.

Emerick, Y. (2000). What Islam is all about. International Books \&Tapes Supply. New York.

Esses, Victoria and Gardner, R. (1996). Multiculturalism in Canada: Context and current status. Canadian Journal of Behavioral Science/Revue canadienne des sciences du comportement, 28(3), 145-152.

Gay, G. (1985). Implications of selected models of ethnic identity development for educators. Journal of Negro Education, 54, 43-44. 
Ghosh, R. (2004). Canada: A multicultural policy. In I. Rothberg (Ed.) Education reform around the globe: Balancing tradition and change (261-282). Lanham, MD.

Hajalton, B. (1982). Islamic moral education: An introduction. Makkah, SA: Umm Al-Qura University Press.

Halstead, J. (2004). An Islamic concept of education. Comparative Education, 40(4), 517-529.

Hewer, C. (2001). Schools for Muslims. Oxford Review of Education, 27(4), 515-527.

Hewitt, I. (2006). The case for Muslim school. The Muslim educational trust. London, UK. Retrieved in January 15, 2006 from: http://www.metrust.demon.co.uk/issues1211/issues72-78.pdf.

Ibn Manzur. (2000). Lisan Al 'Arabi (Arabic Language Dictionary). Retrieved in January 2006 from http: //www.muhadith.com.

Ilene, .H. Agnes, .M. and John,. S. (2011). The Role of Multiculturalism Policy in Addressing Social Inclusion Processes in Canada. Prepared for the Canadian Multicultural Education Foundation, June 1, 2011. Ottawa, ON: Ryerson University, Centre for Voluntary Sector Studies.

Kymlicka, W. (1994). Communitarianism, liberalism, and superliberalism. Critical Review 8 (2), 263-284.

Kymlicka, W. (2006). Immigration, multiculturalism, and the welfare state. Ethics \& international affairs 20(3) Retrieved from http://www.cceia.org/resources/journal/20_3/articles/001.html.

Mawdudi, A. (1988). Towards Understanding Islam: 3rd Ed. Richardson, TX: Alhuda Publishers.

Masood, E. (2007). Muslims and multiculturalism: Lessons from Canada. Open Democracy Press, http://www.opendemocracy.net/globalization/canada_muslims_4414.jsp.

Meer, N., \& Modood, T. (2009). The Multicultural State We are In: Muslims, Multicultural and the Civic Re-balancing of British Multiculturalism. Political Studies, Vol. 57, 473-497.

Merry, M. (2007). Culture, Identity, and Islamic schooling: A philosophical approach. New York: Palgrave Macmillan.

Merry, M. (2005a) Indoctrination, moral instruction and non-rational beliefs: a place for autonomy. Educational theory 55(4), 399-420.

Modood,T. (2005). Multicultural Politics: Racism, Ethnicity, and Muslims in Britain. Minneapolis: University of Minnesota Press.

Nye, M. The Challenge of Multiculturalism. Culture and Religion, 8(2), July 2007, pp. 109-123(15).

Philips, A.A. (1997). Islamic studies. Birmingham, UK: Al-Hidaayah Publication and Distribution.

Ramadan,T. (2004).Islam, the West and the Challenges of Modernity. Leicester, UK: Islamic Foundation.

Sahadat, J. (1997). Islamic education: A challenge to conscience. The America journal of Islamic social sciences 14(4) pp24-29.

Shaikh, K. (1996). A Study of Hadith: Ilm al-hadith, methodology, literature and anthology. Skokie, IL: IQRA International Educational Foundation.

Sleeter and Grant (2006). Making choices for multicultural education: Five approaches to race class and gender. Columbus, $\mathrm{OH}$ : Merrill.

Tan, C. (2011). Where tradition and modern knowledge meet: exploring two Islamic schools in Singapore and Britain. Intercultural education, 22(1), 55-68.

Thomas, J. (2002). Excellence in Islamic education: Key issues for present times. Retrieved in May 20, 2005 from: URL: http://www.thebook.org/Education. 
Zine, J. (2007). Safe havens or religious ghettos: Narratives of Islamic schooling in Canada. Race ethnicity and education, 10(1), pp 71-92. 